\title{
PUBLIC AWARENESS TOWARDS VALUE ADDED TAX (VAT) SYSTEM IN HETAUDA SUB METROPOLITAN CITY AREA
}

\section{Tika Prasad sapkota}

Faculty member, Hetauda School of Management and Social Sciences

\begin{abstract}
Value added tax (VAT) is indirect sources of revenue collection of nation. It has been the most essential choice like our developing countries, Nepal. Which leads to revenue enhancement and sustainable economic development. As VAT was an emerging concept in Nepal, a comprehensive taxpayer education program was launched to impart knowledge regarding the various aspects of VAT to parliamentarians, industrialists, businessmen, consumers as well related society. The study used descriptive and survey research design. Data were collected through questionnaires. Statistical tools were used to make a proper analysis. It is found that $20 \%$ businessmen and $33.33 \%$ consumers are not aware that the Government of Nepal is levying VAT on all kind of products, $36 \%$ consumers are not aware of the fact that you pay VAT whenever you purchase any product, $88 \%$ of the total respondents knowledge on earning from VAT is a major source of revenue for
\end{abstract}


Government, only $44 \%$ response of respondents are in favor of billing system, 33.33\% consumer are not aware about existing rate of VAT in Nepal, $44 \%$ consumers specify the other problem in the present VAT implementation except VAT collection, VAT refund and registration. Most of them ask for tax invoice to get the authenticity of sellers. VAT must be successful and this largely depends upon the public awareness, honesty, faith and morality of tax officials and the business community. There is a need for willpower and action. It is also found that public awareness program and tax education play prime role to increase the VAT revenue in Nepal. The finding of this study is majority of Tax expert and businessmen are aware about VAT system but the training and awareness program is essential.

Keywords: Cascading effect, public awareness, indirect tax, value added

\section{INTRODUCTION}

Economic development and growth are important indicators to reflect the real situation of a country in the overall development of the nation. Therefore, it has been an important concern and target of the government policy tools in any underdeveloped countries like Nepal. Achievement of high rate of economic growth, reduction of income disparities and poverty are few development strategies towards which most of the government efforts have been directed in the developing countries. Tax revenue may be classified as direct tax and indirect tax. Direct taxes comprise of income tax, property tax, vehicles tax etc. these taxes are directly imposed on a person or an organization that bears the tax burden ultimately. Indirect taxes comprise of excise duty, custom duty, sales tax, entertainment tax, value added tax (VAT) etc. These taxes are shifted to other people. In the context of Nepal, direct taxes have a lesser contribution to resource mobilization compared to indirect taxes. Globalization, 
economic liberalization, free market policy, the emergence of regional trade organizations and the World Health Organization may create competition. In these contests custom tariff in to be reduced upped a certain level. The shortfall of revenue in custom tariff in to be replaced by VAT, has become our compulsion. A careful examination of this issue imperative analysis is necessary to implement VAT successfully in the coming days. To evaluate the Nepalese VAT by identifying its present problems, not only from the theoretical aspect but also from the practical experience, this is the subject matter of this study (Gnawali, A. 2018).

A value-added tax (VAT) is a consumption tax placed on a product whenever value is added at each stage of the supply chain, from production to the point of sale. The amount of VAT that the user pays is on the cost of the product, less any of the costs of materials used in the product that have already been taxed. A VAT is levied on the gross margin at each point in the manufacturing-distribution-sales process of an item. The tax is assessed and collected at each stage, in contrast to a sales tax, which is only assessed and paid by the consumer at the very end of the supply chain.(Kagan, J. (2020).

In the context of Nepal, there are two sources of government revenue collection. First is Taxable sources and second is Non-Taxable sources. The taxable sources are also classified into direct tax and indirect tax. The VAT is indirect sources of government revenue collection. Nowadays the VAT is also called broad -based tax because it replaces various types of service tax i.e. Sales tax, Contract tax, Entertainment Tax, Hotel tax etc. The VAT is most recent innovation in the field of taxation. The concept of VAT was developed for the first time by Dr.Wilhelm V.Siemens in Germany in 1919 and now it has been adopted by more than 120 countries.

The concept of VAT in Nepal was introduced in early 1990s.Nepal government indicated its intention to introduce VAT in eighth plan, the finance minister declared to introduce a two-tier sales tax system to make the base of implementing VAT from the fiscal year 1992/93. The parliament of Nepal enacted "Value added tax " Act, 
1995(2052 B.S). Subsequently, VAT regulation was made in 1996. The implementation of VAT was delayed due to political instability and strong opposition from the business community. VAT with single rate of $10 \%$ was fully implemented with the effect from $16^{\text {th }}$ November, 1997 (Mangsir 1,2054 B.S.). The government of Nepal increased the rate of VAT with effect from $16^{\text {th }}$ January 2004 i.e., Magh 1, 2061 B.S. (Dhakal. K.D., Pandey B., Bhattarai. I.P., Koirala.G.P and Bhattarai .R.2019).

VAT is also known as goods and services tax, single business tax, or turnover tax in some countries, applies the equivalent of a sales tax to every operation that creates value. For an example, sheet steel is imported by a machine manufacturer. That manufacturer will pay the VAT on the purchase price, remitting that amount to the government. The manufacturer will then transform the steel into a machine, selling the machine for a higher price to a wholesale distributor. The manufacturer will collect the VAT on the higher price, but will remit to the government only the excess related to the value added (the price over the cost of the sheet steel). The wholesale distributor will then continue the process, charging the retail distributor the VAT on the entire price to the retailer, but remitting only the amount related to the distribution mark-up to the government. The last VAT amount is paid by the eventual retail customer who cannot recover any of the previously paid VAT. For a VAT and sales tax of identical rates, the total tax paid is the same, but it is paid at differing points in the process.

For most of the research work, empirical studies play a vital role to find out the actual status of research subject matters. There have been various empirical studies conducted before and after the implementation of VAT system in Nepal. It is viewed that this system has not been implemented effectively as expected. There was a strong opposition from the business community during the implementation period of VAT. In the beginning period of implementation, there was lack of skilled and trained manpower and officials. Administrative structure was also not set up properly. However, in present context, different informative programs, seminars and meeting are held to make the businessmen, consumers and public aware to the VAT. 


\section{Composition of Tax Revenue in Nepal}

Composition of Tax Revenue in Nepal Tax revenue is divided in to two classes one is direct and the other is indirect. A direct tax is such type of tax, which is imposed upon the person out of his income or property. A direct tax is really paid by the person on whom it is legally imposed. Income tax, property tax, gift tax, vehicle tax and others are the best examples of direct taxes. On the other hand, and indirect tax is such type of tax which is imposed upon any person without direct collecting from him. An indirect tax is imposed on person but paid partially or wholly by another. Sales tax, vat, entertainment tax, custom, excise duty are the good examples of this tax. The figure of direct tax and indirect tax revenue from FY1999/00 to FY2015/16 is presented in the following table:

Table 1.

Composition of Total Tax Revenue (RS. In Billion)

\begin{tabular}{|c|c|c|c|c|c|}
\hline \multirow{2}{*}{ Fiscal year } & $\begin{array}{c}\text { Total Tax } \\
\text { Revenue }\end{array}$ & \multicolumn{2}{|c|}{ Direct Tax } & \multicolumn{2}{c|}{ Indirect Tax } \\
\hline & & Amount & $\%$ & Amount & $\%$ \\
\hline $1999 / 00$ & 3315.21 & 895.15 & 27.00 & 2420.06 & 73.0 \\
\hline $2000 / 01$ & 3886.51 & 1015.94 & 26.34 & 2870.57 & 73.66 \\
\hline $2001 / 02$ & 3933.06 & 1059.75 & 26.94 & 2873.31 & 73.06 \\
\hline $2002 / 03$ & 4258.70 & 1010.58 & 23.73 & 3248.12 & 76.27 \\
\hline $2003 / 04$ & 4817.50 & 1191.26 & 24.73 & 3626.04 & 75.27 \\
\hline $2004 / 05$ & 5410.47 & 1307.18 & 24.16 & 4103.29 & 75.84 \\
\hline $2005 / 06$ & 5743.04 & 1396.81 & 24.32 & 4346.23 & 75.68 \\
\hline $2006 / 07$ & 7112.67 & 1898.03 & 26.69 & 5214.64 & 73.31 \\
\hline $2007 / 08$ & 8515.55 & 2308.77 & 27.11 & 6206.77 & 72.89 \\
\hline $2008 / 09$ & 11705.19 & 3432.07 & 29.32 & 8273.12 & 70.68 \\
\hline $2009 / 10$ & 15978.53 & 4039.60 & 25.28 & 11938.93 & 74.72 \\
\hline $2010 / 11$ & 17722.72 & 4672.03 & 26.36 & 13050.69 & 73.64 \\
\hline $2011 / 12$ & 21172.18 & 5777.02 & 27.29 & 15395.16 & 72.71 \\
\hline
\end{tabular}




\begin{tabular}{|c|c|c|c|c|c|}
\hline Fiscal year & $\begin{array}{c}\text { Total Tax } \\
\text { Revenue }\end{array}$ & \multicolumn{2}{|c|}{ Direct Tax } & \multicolumn{2}{c|}{ Indirect Tax } \\
\hline $2012 / 13$ & 25921.49 & 7301.26 & 28.17 & 18620.23 & 71.83 \\
\hline $2013 / 14$ & 31243.99 & 8673.65 & 27.78 & 22570.34 & 72.22 \\
\hline $2014 / 15$ & 35350.57 & 9966.99 & 28.19 & 25383.50 & 71.81 \\
\hline $2015 / 16$ & 41242.44 & 12056.13 & 29.24 & 29186.31 & 70.76 \\
\hline $2016 / 17$ & 55386.65 & 16727.7 & 30.20 & 38658.95 & 69.8 \\
\hline $2017 / 18$ & 65949.15 & 17922.01 & 27.18 & 48027.14 & 72.82 \\
\hline $2018 / 19$ & 76578.29 & 22805.01 & 29.78 & 53773.28 & 70.22 \\
\hline $2019 / 20$ & 67230.68 & 20969.24 & 31.19 & 46261.44 & 68.81 \\
\hline
\end{tabular}

Source: Economic Survey and Budget Speech, various Issues from 1999/00 to 2019/20, Ministry of Finance, Government of Nepal, 2019/20.

\section{Composition of Indirect Tax Revenue}

The composition of indirect tax in Nepal is presented below in table 4.10. An indirect tax is imposed on one person but paid partly or wholly by another. Indirect tax includes custom duty (export or import duty). Excise duty, VAT and others tax

\section{Table 2.}

Composition of Indirect Tax Revenue (RS. In Billion)

\begin{tabular}{|c|c|c|c|c|c|c|c|c|c|}
\hline \multirow{2}{*}{$\begin{array}{c}\text { Fiscal } \\
\text { Year }\end{array}$} & $\begin{array}{c}\text { Total } \\
\text { Indirect } \\
\text { Tax }\end{array}$ & \multicolumn{2}{|c|}{ Custom Duties } & \multicolumn{2}{|c|}{$\begin{array}{c}\text { Value Added Tax } \\
\text { (VAT) }\end{array}$} & \multicolumn{2}{c|}{ Excise Duties } & \multicolumn{2}{c|}{ Other Taxes } \\
\cline { 5 - 11 } & Amount & \% & Amount & \% & Amount & \% & Amount & \% \\
\hline $1999 / 00$ & 2420.06 & 1081.33 & 44.68 & 1625.97 & 42.40 & 312.76 & 12.92 & - & - \\
\hline $2000 / 01$ & 2870.57 & 1255.21 & 43.73 & 1238.24 & 43.13 & 377.12 & 13.14 & & \\
\hline $2001 / 02$ & 2873.31 & 1265.88 & 44.06 & 1226.73 & 42.69 & 380.70 & 13.25 & & \\
\hline $2002 / 03$ & 3248.12 & 1423.64 & 43.83 & 1345.97 & 41.44 & 478.51 & 14.73 & & \\
\hline $2003 / 04$ & 3626.04 & 1555.48 & 42.90 & 1447.89 & 39.93 & 622.67 & 17.17 & & \\
\hline $2004 / 05$ & 4103.29 & 1570.16 & 38.27 & 1888.54 & 46.03 & 644.59 & 15.70 & & \\
\hline $2005 / 06$ & 4346.23 & 1534.40 & 35.31 & 2161.07 & 49.72 & 650.76 & 14.97 & & \\
\hline $2006 / 07$ & 5214.64 & 1670.76 & 32.04 & 2609.56 & 50.04 & 934.34 & 17.92 & & \\
\hline $2007 / 08$ & 6206.77 & 2106.24 & 33.93 & 2981.57 & 48.04 & 1118.96 & 18.03 & & \\
\hline \hline
\end{tabular}




\begin{tabular}{|c|c|c|c|c|c|c|c|c|c|}
\hline \multirow{2}{*}{$\begin{array}{c}\text { Fiscal } \\
\text { Year }\end{array}$} & \multirow{2}{*}{$\begin{array}{c}\text { Total } \\
\text { Indirect } \\
\text { Tax }\end{array}$} & \multicolumn{2}{|c|}{ Custom Duties } & \multicolumn{2}{|c|}{$\begin{array}{c}\text { Value Added Tax } \\
\text { (VAT) }\end{array}$} & \multicolumn{2}{|c|}{ Excise Duties } & \multicolumn{2}{c|}{ Other Taxes } \\
\cline { 5 - 10 } & Amount & \% & Amount & \% & Amount & \% & Amount & $\%$ \\
\hline $2008 / 09$ & 8273.12 & 2679.29 & 32.39 & 3970.09 & 47.99 & 1622.09 & 19.61 & 1.65 & 0.02 \\
\hline $2009 / 10$ & 11938.93 & 3521.89 & 29.50 & 5492.09 & 46.00 & 2414.76 & 20.23 & 510.19 & 4.27 \\
\hline $2010 / 11$ & 13050.69 & 3571.35 & 27.37 & 6166.36 & 47.25 & 2633.85 & 20.18 & 679.13 & 5.20 \\
\hline $2011 / 12$ & 15395.16 & 4339.06 & 28.19 & 7093.04 & 46.07 & 3001.61 & 19.50 & 961.45 & 6.24 \\
\hline $2012 / 13$ & 18620.23 & 5693.18 & 30.58 & 8341.84 & 44.80 & 3623.47 & 19.46 & 961.74 & 5.16 \\
\hline $2013 / 14$ & 22570.34 & 6798.06 & 30.12 & 10111.06 & 44.80 & 4541.10 & 20.12 & 1120.12 & 4.96 \\
\hline $2014 / 15$ & 25383.50 & 6770.49 & 26.70 & 11216.07 & 44.20 & 5253.00 & 20.70 & 2143.94 & 8.44 \\
\hline $2015 / 16$ & 29186.31 & 7592.91 & 26.00 & 13492.00 & 45.90 & 6336.18 & 21.70 & 1756.22 & 6.40 \\
\hline $2016 / 17$ & 38658.95 & 10305.88 & 26.66 & 19376.34 & 50.12 & 8480.55 & 21.93 & 496.18 & 1.29 \\
\hline $2017 / 18$ & 48027.14 & 12686.54 & 26.41 & 24547.02 & 51.11 & 10257.92 & 21.37 & 535.66 & 1.11 \\
\hline $2018 / 19$ & 53123.28 & 15927.93 & 29.23 & 26455.39 & 49.80 & 10204.98 & 19.21 & 934.96 & 1.76 \\
\hline $2019 / 20$ & 41227.36 & 10871.65 & 26.37 & 20766.22 & 50.37 & 9148.35 & 22.19 & 441.13 & 1.07 \\
\hline
\end{tabular}

Source: Economic Survey and Budget Speech, various Issues from 1999/00 to 2019/20, Ministry of Finance, Government of Nepal, 2019/20.

Statement of The Problem: The VAT is the system created for implementing uniform taxation of goods and services. Now VAT is implemented across the country. At this stage, there is reasonable queries to be posed by the researcher.

What is the status of taxpayers, tax experts and businessmen awareness regarding VAT?

Objective of the Study: The study has been undertaken to study of taxpayers, tax experts and businessmen awareness and effectiveness of VAT in Hetauda Sub Metropolitan city area.

\section{METHODOLOGY}

The study used survey and analytical research design. In course of this study, 80 sets of questionnaires were distributed, out of which only 50 filled questionnaires were collected. The survey was conducted in Hetauda Sub Metropolitan city area. Persons included in the 
sample are carefully selected by the judgment of the researcher. The respondents have been divided into three groups, tax experts, businessmen and consumers. To collect primary data, a set of questionnaires was developed and distributed to the selected respondents in order to get accurate and actual information.

\section{RESULTS AND DISCUSSION}

\subsection{Views on Knowing About VAT}

Proper knowledge about VAT is very important to implement VAT effectively. To know whether the respondents are introduced to VAT or not, a question, "Are you aware that the Government of Nepal is levying VAT on all kind of products?" was asked. The survey provided the following results

Table 3.

Views on Knowing About VAT

\begin{tabular}{|l|l|l|l|l|l|l|l|}
\hline \multirow{3}{*}{ Respondent } & \multicolumn{6}{|c|}{ Response } & Total \\
\cline { 2 - 7 } & \multicolumn{1}{|l|}{ Yes } & \multicolumn{1}{|l|}{ No } & \multicolumn{2}{l|}{ Do not know } & \multirow{2}{*}{ No. } \\
\cline { 2 - 7 } & No & $\%$ & No & $\%$ & No & $\%$ & \\
\hline Tax experts & 10 & $100 \%$ & - & - & - & - & 10 \\
Business men & 8 & $80 \%$ & 2 & $20 \%$ & - & - & 10 \\
Consumer & 20 & $66.67 \%$ & 10 & $33.33 \%$ & - & - & 30 \\
\hline Total & 38 & $76 \%$ & 12 & $24 \%$ & - & - & 50 \\
\hline
\end{tabular}

\section{Source: Field survey, 2021}

Survey results show that most of the respondents are familiar to VAT. It is revealed that $78.33 \%$ of the total respondents know about levying VAT on all kind of products. It included $100 \%$ tax experts, $80 \%$ percent businessmen/traders and $66.67 \%$ consumers. However, 24\% percent of respondents are not familiar with VAT, as $20 \%$ percent businessmen and $33.33 \%$ consumers responded that they have no idea about VAT. It can be concluded that though the majority of people are introduced to VAT, awareness is still required for consumers. 


\subsection{View of payment of VAT whenever you purchase any product}

To know the respondents' knowledge on payment of VAT whenever you purchase any product, a question, are you aware of the fact that you pay VAT whenever you purchase any product?" was asked. The survey result on this aspect is presented below

Table 4.

View of payment of VAT whenever you purchase any product

\begin{tabular}{|l|l|l|l|l|l|l|l|}
\hline \multirow{2}{*}{ Respondent } & \multicolumn{6}{|c|}{ Response } & Total \\
\cline { 2 - 7 } & Yes & \multicolumn{2}{|c|}{ No } & \multicolumn{2}{|l|}{ Do not know } & No. \\
\cline { 2 - 7 } & No & $\%$ & No & $\%$ & No & $\%$ & \\
\hline Tax expert & 10 & $100 \%$ & - & - & - & - & 10 \\
Business men & 4 & $40 \%$ & 3 & $30 \%$ & 3 & & 10 \\
Consumer & - & & 15 & $50 \%$ & 15 & & 30 \\
\hline Total & 14 & $28 \%$ & 18 & $36 \%$ & 18 & $36 \%$ & 50 \\
\hline
\end{tabular}

Source: Field survey, 2021

Survey results show that most of the respondents are not aware of the fact that you pay VAT of any product. It is revealed that $28 \%$ of the total respondents know about VAT on all kind of products. It included $100 \%$ tax experts ,40\% percent businessmen/traders. However, $72 \%$ percent of respondents are not familiar with VAT on purchase of any product.

It can be concluded that though the majority of people are not introduced of payment of VAT whenever you purchase any product, awareness is still required for consumers.

\subsection{View of tax amount is paid by the manufacturer, dealers and after that they levy the same tax on you.}

To know the respondents' knowledge on tax amount is paid by the manufacturer, dealers and after that they levy the same tax on you. A question, do you know that some part of your tax amount is paid by the manufacturer, dealers and after that they levy the same tax on you?" was asked. The survey result on this aspect is presented below 
Table 5.

View of tax amount is paid by the manufacturer, dealers and after that they levy the same tax on you.

\begin{tabular}{|l|l|l|l|l|l|l|l|}
\hline \multirow{2}{*}{ Respondent } & \multicolumn{5}{|c|}{ Response } & Total \\
\cline { 2 - 7 } & \multicolumn{2}{|l|}{ Yes } & No & \multicolumn{2}{l|}{ Do not know } & \multirow{2}{*}{ No. } \\
\cline { 2 - 7 } & No & $\%$ & No & $\%$ & No & $\%$ & \\
\hline Tax expert & 10 & $100 \%$ & - & - & - & - & 10 \\
Business men & 8 & $80 \%$ & 2 & $20 \%$ & - & - & 10 \\
Consumer & - & - & 17 & $56.67 \%$ & 13 & $43.33 \%$ & 30 \\
\hline Total & 18 & $36 \%$ & 19 & $38 \%$ & 13 & $26 \%$ & 50 \\
\hline
\end{tabular}

\section{Source: Field survey, 2021}

Survey results show that most of the respondents are not know about tax amount is paid by the manufacturer, dealers and after that they levy the same tax on you. It is revealed that 36 $\%$ of the total respondents know about VAT paid by the manufacturer, dealers and after that they levy the same tax on you. It included $100 \%$ tax experts ,80\% percent businessmen/traders. However, 64\% percent of respondents are not known VAT paid by the manufacturer, dealers and after that they levy the same tax on you. It included $20 \%$ businessman and 100\% consumer. It can be concluded that though the majority of people are not known VAT paid by the manufacturer, dealers and after that they levy the same tax on you. awareness is still required for consumers and business men about channels of distribution.

\subsection{View of the earning from VAT is a major source of revenue for Government.}

To know the respondents' knowledge on earning from VAT is a major source of revenue for Government. A question, do you think that the earning from VAT is a major source of revenue for Government?" was asked. The survey result on this aspect is presented below 
Table 6.

View of the earning from VAT is a major source of revenue for Government.

\begin{tabular}{|l|l|l|l|l|l|l|l|}
\hline \multirow{2}{*}{ Respondent } & \multicolumn{5}{|c|}{ Response } & Total \\
\cline { 2 - 7 } & \multicolumn{2}{|l|}{ Yes } & No & Do not know & \multirow{2}{*}{ No. } \\
\cline { 2 - 7 } & No & $\%$ & No & $\%$ & No & $\%$ & \\
\hline Tax expert & 10 & $100 \%$ & - & - & - & - & 10 \\
Business men & 10 & $100 \%$ & - & - & - & - & 10 \\
Consumer & 24 & $80 \%$ & 6 & $20 \%$ & - & - & 30 \\
\hline Total & 44 & $88 \%$ & 6 & $12 \%$ & - & - & 50 \\
\hline
\end{tabular}

Source: Field survey, 2021

Survey results show that knowledge on earning from VAT is a major source of revenue for Government. It is revealed that $88 \%$ of the total respondent's knowledge on earning from VAT is a major source of revenue for Government. It included $100 \%$ tax experts ,100\% businessmen/traders and $80 \%$ consumer. However, 12\% percent of respondents are not known knowledge on earning from VAT is a major source of revenue for Government. It included $20 \%$ consumer only.

It can be concluded that though the majority of people are knowledge on earning from VAT is a major source of revenue for Government. awareness is still required for consumers.

\section{5 view about billing system}

To know the respondents' view for billing system. A question, what is your view about billing system?" was asked. The survey result on this aspect is presented below

Table 7.

view about billing system

\begin{tabular}{|l|l|l|l|l|l|l|l|}
\hline \multirow{2}{*}{ Respondent } & \multicolumn{5}{|c|}{ Response } & Total \\
\cline { 2 - 7 } & \multicolumn{2}{|l|}{ Possible } & \multicolumn{2}{|l|}{ Impossible } & \multicolumn{2}{|l|}{ Do not know } & \multirow{2}{*}{ No. } \\
\cline { 2 - 7 } & No & $\%$ & No & $\%$ & No & $\%$ & \\
\hline Tax expert & 10 & $100 \%$ & - & - & - & - & 10 \\
Business men & 7 & $70 \%$ & 3 & $30 \%$ & - & - & 10 \\
Consumer & 5 & $16.67 \%$ & - & - & 25 & $83.33 \%$ & 30 \\
\hline Total & 22 & $44 \%$ & 3 & $6 \%$ & 25 & $50 \%$ & 50 \\
\hline
\end{tabular}

\section{Source: Field survey, 2021}


Survey results show that views for billing system. It is revealed that $44 \%$ response of respondents are possible for billing system. It included $100 \%$ tax experts, $70 \%$ businessmen/traders and $16.67 \%$ consumer. However, $6 \%$ percent response of respondents are impossible for billing system. It included 30\% businessmen only. And 50\% response of respondents are not known about billing system. It included 83.33\% consumer.

It can be concluded that though the majority of consumer are not knowledge on billing system. awareness is still required for consumers.

\subsection{View about rate of VAT in Nepal}

To know the respondents' view for Tax rate. A question, how do you think about existing rate of VAT in Nepal?" was asked. The survey result on this aspect is presented below

Table 8.

View about rate of VAT in Nepal

\begin{tabular}{|l|l|l|l|l|l|l|l|l|l|}
\hline \multirow{2}{*}{ Respondent } & \multicolumn{7}{|c|}{ Response } & Total \\
\cline { 2 - 10 } & High rate & \multicolumn{2}{|l|}{ Low rare } & \multicolumn{2}{l|}{ Moderate rate } & \multicolumn{2}{l|}{ Do not know } & \multirow{2}{*}{ No. } \\
\cline { 2 - 10 } & No & $\%$ & No & $\%$ & No & $\%$ & No & $\%$ & \\
\hline Tax expert & - & - & 6 & $60 \%$ & 4 & $40 \%$ & - & & 10 \\
Business men & 6 & $60 \%$ & - & - & 4 & $40 \%$ & & & 10 \\
Consumer & 10 & $33.33 \%$ & 8 & $26.67 \%$ & 8 & $26.67 \%$ & 4 & $13.33 \%$ & 30 \\
\hline Total & 16 & $32 \%$ & 14 & $28 \%$ & 16 & $32 \%$ & 4 & $8 \%$ & 50 \\
\hline
\end{tabular}

\section{Source: Field survey, 2021}

Survey results show that views for Tax rate. It is revealed that $32 \%$ response of respondents are high rate, $28 \%$ response is low rate, $32 \%$ response are moderate rate, however $4 \%$ response of respondents are do not know about tax rate.

It can be concluded that though the minority of consumer are not knowledge on current Vat rate. awareness is still required. 


\subsection{View of problem of VAT implementation}

To know the respondents' view for problem of VAT implementation. A question, what are the main problem in the present VAT implementation?" was asked. The survey result on this aspect is presented below

Table 9.

View of problem of VAT implementation

\begin{tabular}{|l|l|l|l|l|l|l|l|l|l|}
\hline \multirow{2}{*}{ Respondent } & \multicolumn{7}{|c|}{ Response } & Total \\
\cline { 2 - 9 } & \multicolumn{1}{|l|}{ Registration } & \multicolumn{2}{l|}{ Collection } & \multicolumn{2}{l|}{ VAT refund } & \multicolumn{2}{l|}{ Others } & \multirow{2}{*}{ No. } \\
\cline { 2 - 9 } & No & $\%$ & No & $\%$ & No & $\%$ & No & $\%$ & \\
\hline Tax expert & - & - & 6 & $60 \%$ & 4 & $40 \%$ & - & - & 10 \\
Business men & 6 & $60 \%$ & - & - & 4 & $40 \%$ & - & - & 10 \\
Consumer & - & - & 8 & $26.67 \%$ & - & & 22 & $73.33 \%$ & 30 \\
\hline Total & 6 & $12 \%$ & 14 & $28 \%$ & 8 & $16 \%$ & 22 & $44 \%$ & 50 \\
\hline
\end{tabular}

\section{Source: Field survey, 2021}

Survey results show that views for problem of VAT implementation. It is revealed that $12 \%$ response of respondents are problem in registration, 28\% response are Problem in VAT collection, 16\% response are Problem in VAT refund, However, $44 \%$ response of respondents are specified others problem. Majority response of consumer are shown other problems in VAT implementation.

It can be concluded that though the Vat implementation awareness program is still required to the public.

\subsection{View of VAT effectively successful?}

To know the respondents' view for VAT effectively successful. A question, what kind of efforts is needed to make VAT effectively successful??" was asked. The survey result on this aspect is presented below 
Table 10.

View of VAT effectively successful?

\begin{tabular}{|c|c|c|c|c|c|c|c|c|c|}
\hline \multirow[t]{3}{*}{ Respondent } & \multicolumn{8}{|c|}{ Response } & Total \\
\hline & \multicolumn{2}{|c|}{$\begin{array}{l}\text { Improved } \\
\text { administration }\end{array}$} & \multicolumn{2}{|c|}{$\begin{array}{l}\text { Trained } \\
\text { Human } \\
\text { resources }\end{array}$} & \multicolumn{2}{|c|}{$\begin{array}{l}\text { Improved } \\
\text { VAT laws } \\
\text { and } \\
\text { regulation }\end{array}$} & \multicolumn{2}{|c|}{$\begin{array}{l}\text { Public } \\
\text { awareness } \\
\text { program }\end{array}$} & No. \\
\hline & No & $\%$ & No & $\%$ & No & $\%$ & No & $\%$ & \\
\hline Tax expert & 1 & $10 \%$ & - & - & 4 & $40 \%$ & 5 & $50 \%$ & 10 \\
\hline Business men & 4 & $40 \%$ & 2 & $20 \%$ & 2 & $20 \%$ & 2 & $20 \%$ & 10 \\
\hline Consumer & 4 & $40 \%$ & 8 & $26.67 \%$ & - & & 18 & $60 \%$ & 30 \\
\hline Total & 9 & $18 \%$ & 10 & $20 \%$ & 6 & $12 \%$ & 25 & $50 \%$ & 50 \\
\hline
\end{tabular}

\section{Source: Field survey, 2021}

Survey results show that views for VAT effectively successful. It is revealed that $18 \%$ response of respondents are in favor of Improved administration, 20\% response are in favor of Trained Human resources, 12\% response are in favor of Improved VAT laws and regulation, However, 50\% response of respondents are in favor of public awareness program. Majority response of respondents are in favor of public awareness program.

\section{CONCLUSION}

VAT is broad base tax. It avoids all types of indirect tax and emerged single name VAT. eliminates cascading effect of tax, creates and investment friendly tax system, have a simple and modern tax system that exempted export and basic goods from taxation and finally increases revenue by using Tax credit method. This is a matter of great pride that Nepal has entered into a major global tax system with the introduction of VAT.

From above finding, It is found that $20 \%$ businessmen and $33.33 \%$ consumers are not aware that the Government of Nepal is levying VAT on all kind of products, 36\% consumers are not aware of the fact that you pay VAT whenever you purchase any product, 
$88 \%$ of the total respondents knowledge on earning from VAT is a major source of revenue for Government, only $44 \%$ response of respondents are in favor of billing system, 33.33\% consumer are not aware about existing rate of VAT in Nepal, 44\% consumers specify the other problem in the present VAT implementation except VAT collection ,VAT refund and registration. 18\% response of respondents are in favor of Improved administration, 20\% response are in favor of Trained Human resources, 12\% response are in favor of Improved VAT laws and regulation, However, 50\% response of respondents are in favor of public awareness program.

Theoretically, the Nepalese VAT system has strong rules and regulation. It is one of the best models in the world. However, practically the system is not effective even today. Most of the problems concerning the operation of VAT in Nepal have been identified. The major problem or reason behind all the problems is lack of consumers awareness regarding VAT. Empirically, VAT is found to be the best source for reducing economic inefficiencies of the nation and contributes greatly in revenue potential of the nation. These findings have been supported by the field study. Hence, the main point to be considered is that there is a positive relationship between the taxpayers' awareness and revenue collection of nation i.e. increasing a number of taxpayers would, of course contribute in increasing revenue potential of the nation. This puts forward the need for encouraging taxpayers for voluntary compliance and any reforms of tax administration should also aimed at motivating taxpayers on it. VAT must be successful and this largely depends upon the public awareness, honesty, faith and morality of tax officials and the business community. The government needs full cooperation from the tax administration, the taxpayers and businesspersons as well as consumers in its effort to generate more revenue. The government should focus the public awareness program through seminar, conference, talk program and mass publicity to increase the VAT revenue. It can be concluded that though public awareness program is required for VAT effectively successful. 


\section{Reference}

Casenegra, J. M., Miche, G., \& George, E. L. (1973). The Value added tax in developing countries. IMP Staff Papers, 20(2). International Monetary Fund

Dahal. NEFAS. Dhakal, A. (2015). Nepalese tax structure in Nepal. Journal of Finance and Accounting, 23( 4),27-38.

Dhakal. K.D., Pandey B., Bhattarai. I.P., Koirala.G.P and Bhattarai. R (2019). Fundamentals of Taxation and Auditing.Asmita books and publication.Kathmandu,Nepal

Gnawali, A. (2018). Tax Payers' Knowledge Towards Value Added Tax in Nepal. Journal of Nepalese Business Studies, 11(1), 76-86.

Gyawali, A. (2013).Tax payer awareness regarding VAT collection in Nepal. Nepalese

Kagan, J. (2020, August 28). What Is a Value-Added Tax (VAT)?

Le, Z. ( 1992). Tax payer and their awareness for effectiveness of VAT. Journal of Economic Development, 9(3), 45-67.

Ministry of Finance (2019/20). Economic Survey. Kathmandu: Ministry of Finance.

Ministry of Finance (2019). Revenue Advisory Committee Report.

Misra, R. (2014). The impact of taxpayer education on tax. Tax compliance in SouthAfrica, 2(5), 18-29.

Poterba, J. M. (1997). Retail price reactions to changes in state and local sales taxes. National Tax Journal, 49(2), 149-65.

Shrestha, S. (1999). Consumers' awareness necessary for success of VAT. Nepalese Management Review, 9(1), 40-49 